\title{
EFEK KOMBINASI SPIRULINA KITOSAN UNTUK PRESERVASI SOKET TERHADAP OSTEOBLAS, OSTEOKLAS DAN KEPADATAN KOLAGEN
}

\author{
(EFFECT SPIRULINA CHITOSAN COMBINATION AS A SOCKET \\ PRESERVATION TOOSTEBLAST, OSTEOCLAST, \\ AND COLLAGEN DENSITY)
}

\author{
Sherman Salim, Rostiny, Mefina Kuntjoro \\ Departemen Prostodonsia \\ Fakultas Kedokteran Gigi, Universitas Airlangga Surabaya \\ J1. Prof Dr Moestopo 47 Surabaya \\ E-mail: sherman.salim@yahoo.com
}

\begin{abstract}
Socket preservation is needed to support prosthodontic treatment as prominent alveolar bone is very important due to denture retention and stability. Material that able to prevent excessive bone resorption and improve bone remodelling is necessary to apply into socketpost extraction. Spirulina has antiinflamation and antioxidant properties meanwhile chitosan has mucoadhesive activity. Combination of both material can give sinergic reaction. This research can get appropriate socket preservation material. Twenty eight cavia cobayas divided into 4 groups. After extraction, socket post extraction control group was filled with $\mathrm{CMC} \mathrm{Na} 3 \%$, group I spirulina $12 \%$, group II chitosan $20 \%$, group III combination spirulina $12 \%$ chitosan $20 \%$. On day $14^{\text {th }}$, Cavia cobayas was terminated and mandible was taken. Histopathology examination on the amount of osteoblast, osteoclast, collagen, and statistic analysis was done.Data was statistically analise using Kruskal Wallis test. There is significant different between control group and group I, II and III. The highest amount of osteoblast, collagen and the lowest amount of osteoclast was calculated in group III. In conclusion, combination spirulina 12\% chitosan $20 \%$ can increase the amount of osteoblas and collagen and reduce the amount of osteoclast on day $14^{\text {th }}$.
\end{abstract}

Key word: Spirulina, chitosan, socket preservation

\begin{abstract}
Abstrak
Soket preservasi merupakan tindakan penting dilakukan sehubungan dengan perawatan di bidang prostodonsia yang memerlukan bentukan tulang yang prominen sebagai retensi dan stabilitas untuk pemakaian gigi tiruan. Bahan yang dapat mencegah inflamasi berlebihan dan meningkatkan remodeling tulang perlu diaplikasikan pada soket pasca pencabutan. Biomaterial spirulina memiliki sifat antiinflamasi dan antioksidan serta kitosan yang memiliki sifat mucoadhesive akan dikombinasikan karena memiliki efek sinergis apabila digabungkan. Tujuan penelitian ini adalah untukmendapatkan biomaterial yang memberikan efek untuk preservasi soket. Sebanyak 28 ekor Cavia cobaya (marmot) dibagi menjadi 4 kelompok perlakuan. Setelah dilakukan pencabutan, pada soket kelompok kontrol diinduksi gel CMC Na 3\%, kelompok I diinduksi gel spirulina 12\%, kelompok II diinduksi gel kitosan $20 \%$, kelompok III diinudksi gel kombinasi spirulina $12 \%$ kitosan $20 \%$. Pada hari ke 14, hewan coba dieksekusi dan diambil mandibulanya. Kemudian dilakukan pemeriksaan histopatologi jumlah osteoblas, osteoklas dan kolagen pada daerah 1/3 soket. Data hasil pemeriksaan dianalisis menggunakan Kruskal Wallis test. Pada pemeriksaan hari ke 14 terdapat perbedaan signifikan antara kelompok kontrol dan kelompok perlakuan. Jumlah osteoblas dan kolagen paling tinggi pada kelompok III dan jumlah osteoklas paling rendah pada kelompok III. Sebagai kesimpulan, kombinasi spirulina 12\% dan kitosan 20\% meningkatkan jumlah osteoblas dan kolagen dan menurunkan jumlah osteoklas pada hari ke 14
\end{abstract}

Kata kunci: Spirulina, kitosan, preservasi soket 


\section{PENDAHULUAN}

Gigi merupakan organ keras yang memiliki fungsi utama pengunyahan dan memiliki peranan penting terhadap tampilan dari wajah. Jika kerusakan gigi tidak dapat dirawat dan dipertahankan maka harus dilakukan pencabutan gigi. Pencabutan gigi adalah tindakan pengeluaran gigi dari soketnya. Ada beberapa contoh indikasi dalam pencabutan gigi, yaitu karena penyakit periodontal, karies yang parah, dan infeksi periapikal. ${ }^{1}$

Riset kesehatan dasar (RISKESDAS) departemen kesehatan republik Indonesia tahun 2007 melaporkan bahwa kehilangan gigi kelompok usia 45-54 th terdapat 1,8\%, kelompok usia 55-64 th terdapat 5,9\% dan kelompok usia 65 keatas terdapat $17,6 \%{ }^{2}$

Bidang prostodonsia merupakan ilmu kedokteran gigi yang mampu merehabilitasi fungsi oral dengan cara menggantikan gigi yang hilang tersebut beserta jaringan lunak rongga mulut dengan pembuatan restorasi gigi pengganti. Perawatan di bidang prostodonsia memerlukan bentukan tulang yang prominen sebagai retensi dan stabilitas untuk pemakaian gigi tiruan.

Terapi yang digunakan selama ini untuk menghasilkan regenerasi tulang adalah bone graft. Bone graft merupakan bahan yang dapat merangsang penyembuhan tulang melalui proses osteogenesis, os-teoinduction dan osteoconduction. Bahan yang digunakan dalam bone graft dapat dibagi menjadi beberapa kategori utama, yaitu autografts, allografts, dan xenografts. Masing-masing pilihan ini memiliki kelebihan dan kekurangan. Kelemahan dari autograft yaitu tulang harus diambil dari bagian tubuh lain pasien yang sama sehingga dapat menimbulkan masalahmasalah klinis, terbatasnya tulang yang ada, dan dapat menimbulkan resiko kematian. Sedangkan allograft dan xenograft dapat menimbulkan reaksi autoimun serta kemungkinan terjadinya transfer penyakit. Selain itu, biaya bone graft tergolong cukup mahal bagi para pasien yang kurang mampu. ${ }^{3}$

Pada saat ini banyak penelitian obat alternatif yang mengarah pada bahan-bahan yang berasal dari alam karena dianggap lebih sederhana, murah, dan kurang memberikan efek samping yang berbahaya. Spirulina adalah ganggang renik (mikroalga) yang multiselular berbentuk filamen (benang) yang tersusun atas sel-sel berbentuk silindris dan berwarna hijau kebiruan karena adanya klorofil (hijau) dan pigmen phycocyanin (biru). ${ }^{4}$ Spirulina mengandung nutrisi yang sangat bermanfaat bagi tubuh, seperti $C-p h y$ cocyanin, beta-carotenoids, vitamin e, zinc, dan banyak trace element alami lainnya. ${ }^{5}$ Biomassa Spirulina merangsang proses biologis penting dan berperan sebagai anti-alergenik, anti-bakteri, anti-jamur, anti- inflamasi, sifat anti-oksidan, dan imuno-modulasi, sehingga Spirulina termasuk scaffold yang merangsang pertumbuhan sel dan regenerasi jaringan. ${ }^{6}$

Kitosan adalah polisakarida yang terdiri dari glukosamin dan unit $N$-acetyllglucosamine. Kitosan merupakan kitin yang berasal dari polimer yang dihasilkan oleh deasetilasi kitin. Banyak aplikasi biomedis dilakukan dengan bahan kitosan, yaitu seperti penyembuhan luka, pencangkokan kulit, homeostatis, hemodialysis, pencegahan plak gigi, kontrol hipertensi, dan kontrol kolesterol. Kitosan mempunyai sifat osteokonduktifitas tinggi, pengaplikasian yang mudah dan biodegradasi bertahap yang membuat bibit yang bagus untuk regenerasi tulang. Kitosan telah terbukti dapat meningkatkan regenerasi tulang pada dental bone loss, oleh karena itu, kitosan dianggap sebagai alternatif yang cocok untuk bone graft. ${ }^{7}$ Kombinasi kitosan dengan biomaterial lain dapat memiliki efek sinergis pada adhesi sel, diferensiasi sel dan pembentukan matriks ekstraseluler. ${ }^{8}$

Penelitian sebelumnya tentang efek kombinasi spirulina kitosan dengan berbagai macam konsentrasi telah dilakukan dan didapatkan hasil bahwa induksi kombinasi spirulina $12 \%$ dan kitosan $20 \%$ dapat meningkatkan jumlah osteoblas dan kolagen namun tidak berbeda secara bermakna pada jumlah osteoklas pada hari ke $30 .{ }^{9}$ Untuk membuktikan bahwa kombinasi kedua bahan bersifat sinergis maka dilakukan penelitian lanjutan menggunakan dosis tunggal spirulina $12 \%$, kitosan $20 \%$ dan kombinasi spirulina $12 \%$ kitosan $20 \%$. Berdasarkan penelitian tersebut dilakukan penelitian dengan menggunakan kombinasi spirulina $12 \%$ kitosan $20 \%$, serta menunjukkan bahwa gel spirulina dengan konsentrasi $12 \%$ merupakan dosis paling efektif dalam membantu pembentukan sel osteoblast dan proses remodeling tulang. Pada penelitian ini pemeriksaan histopatologi pada hari ke 14, karenamerupakan awal mulai terbentuknya tulang baru pasca ekstraksi gigi. ${ }^{10}$ Penelitian ini bertujuan untuk mendapatkan bahan yang efektif untuk preservasi soket pasca pencabutan gigi sehingga dapat menunjang keberhasilan perawatan di bidang Prostodonsia.

\section{BAHAN METODE}

Jenis penelitian ini adalah eksperimental laboratoris dengan menggunakan rancangan post test only control group design. Penelitian dilakukan di Laboratorium Biokimia Fakultas Kedokteran Universitas Airlangga, pembuatan preparat dilakukan di Laboratorium Patologi Anatomi RSUD Dr Soetomo dan pemeriksaan histopatologi dilakukan di Laboratorim Mikrobiologi Fakultas Kedokteran Gigi Universitas Airlangga. Penelitian telah lolos uji laik etik No: 84/ 
KKEPK.FKG/VIII/2015.Hewan coba yang digunakan dalam penelitian ini adalah cavia cobaya jantan berumur 2-3 bulan dengan berat badan rata-rata 300 gram. Jumlah cavia cobaya yang digunakan 28 ekor yang dibagi menjadi 4 kelompok perlakuan masingmasing 7 ekor. Hewan coba dipelihara selama 3 hari untuk beradaptasi dengan kandang berukuran $60 \mathrm{~cm}$ x $65 \mathrm{~cm}$ x $80 \mathrm{~cm}$ (tiap kandang berisi 7 ekor) dan ditempatkan dalam ruangan yang cukup cahaya agar tidak lembab, jauh dari kebisingan dan tidak terpapar sinar matahari langsung. Makanan yang diberikan adalah jagung dan wortel segar.

Spirulina yang dipakai merupakan sediaan siap jadi dalam bentuk bubuk yang diproduksi oleh Wellness USA. Kitosan berupa sediaan jadi dalam bentuk bubuk berasal dari cangkang udang yang diproduksi oleh Bank Jaringan RSUD Dr. Soetomo. Gel spirulina dan kitosan merupakan hasil pencampuran bubuk spirulina dan kitosan yang dicampur lagi dengan basis gel CMC Na 3\% untuk menghasilkan konsistensi gel yang stabil. Basis gel CMC Na 3\% ini tidak mempengaruhi fungsi dari zat yang dikentalkan dan tidak berpengaruh pada hasil penelitian karena itu digunakan sebagai perlakuan kepada kelompok kontrol.

Pada kelompok kontrol soket diinduksi CMC Ba $3 \%$. Kelompok I diinduksi spirulina $12 \%$ dengan cara mencampur 1,2 gram spirulina dan 8,8 gram CMC $\mathrm{Na} 3 \%$. Kelompok II diinduksi kitosan 20\% dengan cara mencampur 2 gram kitosan dan 8 gram CMC Na3\%Kelompok III diinduksi kombinasi spirulina $12 \%$ kitosan $20 \%$ dengan cara mencampur 1,2 gram spirulina, 2 gram kitosan, dan 6,8 gram CMC Na3\%.

Perlakuan pada cavia cobaya dilakukan dengan pencabutan gigi incisivus kiri rahang bawah dengan menggunakan modifikasi dari needle holder dibawah efek anestesi ketamin 22-44 mg/ kg BB dan diazepam 3-5 mg/kg BB dengan injeksi intra muscular. ${ }^{11}$ Setelah dilakukan pencabutan, luka yang berupa soket diinduksi dengan gel yang telah disiapkan dengan menggunakan syringe sebanyak $0,1 \mathrm{cc}$, kemudian soket bekas pencabutan ditutup dengan dijahit menggunakan benang silk 3/0.Hewan coba dipelihara kembali dengan pemberian makanan dan memperhatikan kesehatannya. Pada hari ke 14, hewan coba dieksekusi dengan pemberian anestesiketamin 22-44 mg/ kg BB dan diazepam 3-5 mg/kg BB dengan injeksi intra muscularuntuk melepas mandibula kemudian dilakukan dekalsifikasi dengan EDTA $10 \%$ selama 30 hari agar jaringan tulang mandibula menjadi lunak sehingga dapat dilakukan pemotongan pada daerah soket incisivus. Pemotongan berbentuk persegi panjang dalam arah sagital. Hasil potongan dimasukkan dalam formalin buffer
10\% selama 24 jam. Selanjutnya diproses untuk pembuatan preparat histopatologi anatomi(HPA) dengan pengecatan haematocylin eosin (HE).

Pengamatan dilakukan pada preparat HPA yang dibagi menjadi 5 lapang pandang secara acak dengan tekhnik counting menggunakan beta counter. Regio yang akan dihitung yaitu regio yang diberi perlakuan, dalam hal ini soket yang diisi dengan gel. Penghitungan jumlah sel osteoklas,osteoblas dan kolagen dilakukan dengan mikroskop lensa binokuler dengan pembesaran $400 \mathrm{x}$ yang dihubungkan langsung dengan komputer.

Kolagen yang diamati secara mikroskopis berbentuk tebal, berliku-liku, tidak elastis yang terdiri dari protein kolagen (white fibers). Pada pewarnaan dengan pengecatan HE (Hematoksilin Eosin) didapatkan warna merah muda. Pengamatan dengan pengamatan foto dari soket pasca ekstraksi kemudian dilakukan penghitungan jumlah kolagen. Area yang dinilai kepadatannya pada pemeriksaan ini adalah daerah healing centre (HC) yaitu pada daerah di sekeliling tepi soket. Data pada sampel ini merupakan data semikuantitatif, dimana sabut kolagen dinyatakan dalam persen, yang ditentukan dengan cara membagi luas area $\left(\mu \mathrm{m}^{2}\right)$ sabut kolagen yang teramati dengan luas total area pengukuran. Pengukuran dilakukan dengan menggunakan software pengolah gambar Nikon Image System yang telah terkalibrasi, pada gambar dengan pembesaran 400x. Mikroskop yang digunakan pada pemeriksaan ini adalah mikroskop cahaya biasa merk NikonH600L yang dilengkapi dengan digitalcameraDSFi2 300 megapixel dan software pengolah gambar. ${ }^{12}$

Sel osteoblas apabila diamati secara mikroskopis berbentuk kuboid atau silindris pendek, memiliki satu inti sel, dan sitoplasma berwarna merah kebiruan. Sel osteoklas adalah sel yang diamati secara mikroskopis berupa sel raksasa multinukleus berbentuk bulat atau lonjong, sitoplasma berwarna merah kebiruan dan permukaan yang berada pada sisi tulang yang diresorpsi sedikit kasar. ${ }^{13}$

Data yang diperoleh diuji normalitas data dengan One-simple Kolmogorov Smirnov Test kemudian dilakukan uji homogenitas dengan Levene Statistic. Setelah diperoleh data yang homogen kemudian dianalisis dengan uji statistik one way ANOVA dan dilanjutkan dengan Tukey HSD untuk melihat secara signifikan perbedaan bermakna dari hasil 4 kelompok.

\section{HASIL}

Hasil penelitian tentang jumlah kepadatan kolagen, jumlah osteoblas dan osteoklas dapat dilihat pada gambar 1 . 


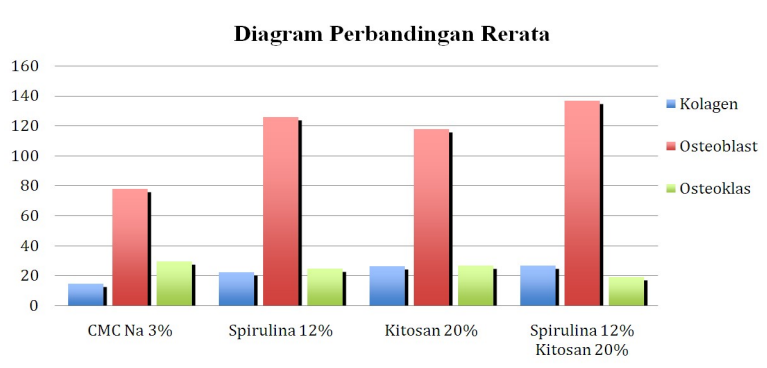

Gambar 1. Diagram batang rata-rata dari hasil pemeriksaan histopatologi kepadatan kolagen, osteoblast, dan osteoklas pada kelompok kontrol, kelompok I (Spirulina 12\%), kelompok II (Kitosan 20\%), dan kelompok III (Spirulina 12\% + Kitosan 20\%)

Gambar 1 menunjukkan jumlah rerata (dalam presentase) tampak kepadatan kolagen pada kelompok I sebesar 22,57, kelompok II sebesar 26,57, dan kelompok III sebesar 26,71 lebih banyak daripada jumlah rerata kepadatan kolagen pada kelompok kontrol yaitu sebesar 14,71. Hasil menunjukkan bahwa kelompok III dengan aplikasi kombinasi spirulina 12\% dan kitosan $20 \%$ merupakan rata-rata dengan hasil tertinggi, yaitu 26,71. Hasil terendah ditunjukkan pada kelompok I dengan aplikasi spirulina $12 \%$, yaitu 22,57.

Jumlah rerata sel osteoblast pada kelompok I sebesar 125,85 mengalami peningkatan dibandingkan kelompok kontrol yaitu sebesar 78,14. Pada jumlah rerata kelompok II yaitu sebesar 117,85 mengalami penurunan dibandingkan kelompok I. Pada kelompok III yaitu sebesar 136,57 mengalami peningkatan dibandingkan kelompok II. Hasil menunjukkan jumlah rerata sel osteoblast tertinggi pada kelompok III dengan pemberian gel kombinasi spirulina $12 \%$ dan kitosan $20 \%(136,57)$ dan jumlah rerata sel osteoblast terendah pada kelompok kontrol dengan pemberian gel CMC-Na 3\% $(78,14)$.

Jumlah rerata sel osteoklas pada kelompok I sebesar 25,00 mengalami penurunan dibandingkan kelompok kontrol yaitu sebesar 29,57. Rerata jumlah sel osteoklas pada kelompok II yaitu sebesar 27,00 mengalami peningkatan dibandingkan kelompok I, namun mengalami penurunan dibandingkan kelompok kontrol. Pada kelompok III pengisian kombinasi spirulina $12 \%$ kitosan $20 \%$ mengalami penurunan dibandingkan kelompok I $(29,57)$, kelompok II $(25,00)$, dan kelompok III $(27,00)$.

Berdasarkan hasil yang diperoleh, dilakukan uji analisis One Way Anova untuk mengetahui perbedaan jumlah kepadatan kolagen dan jumlah osteoblast diantara 4 kelompok. Untuk melakukan uji One Way
Anova terdapat dua syarat yang harus dipenuhi, yaitu distribusi data normal dan mempunyai variasi data sama (homogen). Untuk menguji distribusi data tiap kelompok menggunakan One-Sample Kolmogrov Smirnov Test, sedangkan untuk menguji data variasi homogenitas menggunakan Levene Statistic.

Tabel 1. Uji One - Sample Kolmogorov

\begin{tabular}{lllll}
\hline & \multicolumn{4}{c}{ Signifikansi (p) } \\
\hline Kolagen &, $752^{*}$ &, $764^{*}$ &, $991^{*}$ &, $978^{*}$ \\
Osteoblas &, $992^{*}$ &, $468^{*}$ &, $974^{*}$ &, $936^{*}$ \\
Osteoklas &, $959^{*}$ &, $905^{*}$ &, $996^{*}$ &, 916 \\
\hline
\end{tabular}

*Signifikansi

Pada ketiga variable diperoleh distribusi data normal karena $p>0,05$. Kemudian dilanjutkan dengan uji Levene statistic untuk melihat homogenitas keempat kelompok tersebut.

Tabel 2. Uji Levene statistic

\begin{tabular}{lc}
\hline & Signifikansi (p) \\
\hline Kolagen &, $366^{*}$ \\
Osteoblas &, $121^{*}$ \\
Osteoklas &, 030 \\
\hline
\end{tabular}

Hasil uji Levene statisticini menunjukkan bahwa osteoklas memiliki nilai signifikansi, $030(<0,05)$, sehingga dapat disimpulkan bahwa varians jumlah sel osteoklas pada penelitian ini tidak homogen sehingga tidak dapat dilakukan uji Oneway Anova.

Uji analisis dilanjutkan dengan menggunakan Kruskal-Wallis test. Selanjutnya melakukan uji analisis statistik untuk membandingkan data antar kelompok dengan uji Post hoe test-tukey HSD yang hasilnya dapat dilihat pada tabel 5.2. Dari analisis ini dapat diketahui kelompok-kelompok mana yang memiliki perbedaan signifikan atau bermakna.

Hasil uji analisis Tukey HSD menunjukan bahwa perbedaan kepadatan kolagen antara kelompok kontrol dengan kelompok perlakuan II dan III signifikan. Terdapat perbedaan jumlah osteoblas yang signifikan antara kelompok kontrol dengan kelompok perlakuan I, II, dan III. Perbedaan jumlah osteoklas yang signifikan didapatkan antara kelompok kontrol dengan kelompok perlakuan III.

Hasil pembacaan HPA setelah induksi spirulina $12 \%$, kitosan $20 \%$ dan kombinasi spirulina $12 \%$ kitosan $20 \%$ pada hari ke 14 menunjukkan peningkatan kepadatan kolagen, jumlah osteoblas dan penurunan jumlah osteoklas seperti yang terlihat pada gambar dibawah ini. 
Tabel 3. Tes Tukey HSD kolagen, osteoblas, osteoklas

\begin{tabular}{|c|c|c|c|c|c|}
\hline & & Kontrol & Kelompok I & Kelompok II & Kelompok III \\
\hline \multirow[t]{4}{*}{ Kolagen Kontrol } & & - & - & $*$ & $*$ \\
\hline & Kelompok I & - & - & - & - \\
\hline & Kelompok II & $*$ & - & - & - \\
\hline & Kelompok III & $*$ & - & - & - \\
\hline \multirow[t]{4}{*}{ Osteoblas Kontrol } & & - & $*$ & $*$ & $*$ \\
\hline & Kelompok I & $*$ & - & - & - \\
\hline & Kelompok II & $*$ & - & - & - \\
\hline & Kelompok III & $*$ & - & - & - \\
\hline \multirow[t]{4}{*}{ Osteoklas Kontrol } & & - & - & - & $*$ \\
\hline & Kelompok I & - & - & - & - \\
\hline & Kelompok II & - & - & - & - \\
\hline & Kelompok III & $*$ & - & - & - \\
\hline
\end{tabular}

Keterangan : * signifikan

Kelompok I : diinduksi Spirulina 12\%

Kelompok II : diinduksi Kitosan 20\%

Kelompok III: diinduksi kombinasi Spirulina 12\% Kitosan 20\%
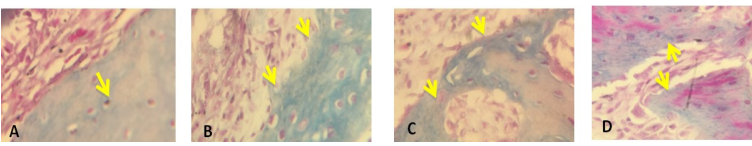

Gambar 2. Tanda panah menunjukkan kepadatan kolagen (warna biru) pada soket gigi marmot: A. Kelompok Kontrol (CMCNa 3\%); B. Kelompok I (Spirulina 12\%); C. Kelompok II (Kitosan 20\%); D. Kelompok III (Spirulina 12\% + Kitosan $20 \%$ )
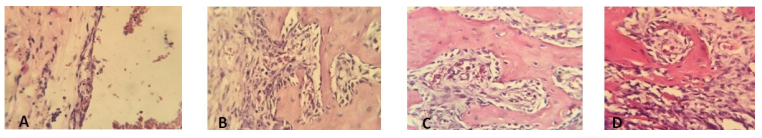

Gambar 3. Pemeriksaan HPA menunjukkan sel osteoblast pada soket gigi marmot: A. Kelompok Kontrol (CMCNa 3\%); B. Kelompok I (Spirulina 12\%); C. Kelompok II (Kitosan 20\%); D. Kelompok III (Spirulina 12\% + Kitosan 20\%)
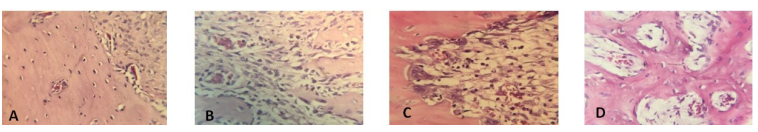

Gambar 4. Pemeriksaan HPA menunjukkan sel osteoklas pada soket gigi marmot: A. Kelompok Kontrol (CMCNa 3\%); B. Kelompok I (Spirulina $12 \%$ ); C. Kelompok II (Kitosan 20\%); D. Kelompok III (Spirulina 12\% + Kitosan 20\%)

\section{PEMBAHASAN}

Hasil analisis statistik pada penelitian menunjukkan adanya peningkatan persentase kepadatan kolagen dan jumlah sel osteoblast serta mengalami penurunan jumlah sel osteoklas pada kelompok I yang diinduksi spirulina $12 \%$ dibandingkan dengan kelompok kontrol. Hal ini disebabkan karena spirulina mengandung Phycocyanin dan $\beta$-karoten yang memiliki aktifitas sebagai antiinflamasi dan antioksidan.
Penelitian secara in vitro dan di vivo model eksperimental menggunakan tikus menunjukkan hasil bahwa phycyocyanin memberikan efek penghambatan TNF- $\alpha$ dan berperan sebagai antioksidan. ${ }^{10}$ Sitokin $\mathrm{TNF}-\alpha$ menstimulus inflamasi dengan merangsang fagosit mononuklear untuk mensekresi sitokin IL$1 \beta$. Sitokin IL-1 $\beta$ bersama dengan TNF- $\alpha$ menggerakkan neutrofil dan monosit ke tempat inflamasi untuk menyingkirkan antigen atau stimulus terjadinya inflamasi, merangsang fagosit mononuklear untuk mensekresi IL-1 $\beta .^{11}$ Penurunan mediator proinflamasi mengakibatkan pembentukan dan aktivitas osteoklast terhambat sehingga osteoblast melakukan proliferasi dan diferensiasi untuk menjadi osteoblast yang matur sehingga jumlah osteoblast meningkat dan kepadatan tulang akan meningkat pula. ${ }^{12}$ Kelompok I (spirulina 12\%) terbukti efektif pada variabel kolagen dilihat dari hasil yang menunjukkan persentase kepadatan kolagen yang lebih tinggi dibandingkan dengan kelompok control (Gambar 2). Kelompok I pada penelitian ini dapat membuktikan bahwa spirulina efektif dalam mengurangi inflamasi yang terjadi pada luka pasca ekstraksi gigi yang ditunjukkan dengan adanya perbedaan signifikan data jumlah rerata sel osteoblast yang lebih tinggi pada kelompok I dibandingkan kelompok kontrol (Gambar 3).

Sitokin proinflamatori yang melibatkan sekresi TNF$\alpha$ dan IL-1 $\beta$ dapat berperan langsung dalam menurunkan tingkat RUNX2 pada diferensiasi osteoblas yang dihasilkan stem cell mesenchymal multipotent sehingga produksi kolagen bisa menurun. Dengan adanya aktifitas antiinflamasi dari spirulina maka sekresi TNF- $\alpha$ dan IL-1 $\beta$ akan menurun dan tidak menghambat RUNX2 dalam memproduksi matriks protein tulang sehingga dapat mensintesa kolagen lebih banyak. ${ }^{13,14}$ Antioksidan yang dikandung spirulina mampu menekan efek destruktif oksidan radikal pada sistem seluruh tubuh dan meningkatkan penyembuhan kerusakan tulang karena ketika terjadi 
kerusakan tulang, radikal bebas yang dihasilkan oleh jaringan rusak akan menimbulkan kerusakan kolagen tulang lebih lanjut. ${ }^{15}$

Kandungan spirulina bermanfaat lainnya dalam aktivitas inflamasi adalah flavonoid. Senyawa aktif yang dapat menurunkan kadar NF - kB adalah flavonoid. ${ }^{16}$ Flavonoid juga akan menghambat lipopolisakarida (LPS) yang menstimulasi NF-kB dengan induksi fosforilasi IkB pada makrofag. Setelah penghambatan $\mathrm{Nf}-\mathrm{kB}$ maka mediator proinflamasi seperti $\mathrm{IL}-6$ juga ikut menurun. ${ }^{17} \mathrm{IL}-6$ berpotensi sebagai stimulator diferensiasi osteoklas, resorpsi tulang dan menghambat osteogenesis yang menyebabkan penurunan jumlah osteoblas. ${ }^{18}$ Pada penelitian ini ter-bukti bahwa kelompok I (spirulina 12\%) dapat me-nurunkan jumlah osteoklas dilihat dari hasil jumlah rerata sel osteoklas yang lebih rendah dibandingkan dengan kelompok kontrol.

Hasil analisis statistik pada penelitian kelompok II dengan diisi kitosan $20 \%$ dibandingkan dengan kelompok kontrol menunjukkan adanya peningkatan kepadatan kolagen, peningkatan jumlah osteoblast serta penurunan jumlah sel osteoklas. Hasil tersebut menunjukkan bahwa kitosan $20 \%$ lebih efektif dibandingkan dengan kelompok kontrol. Hidaka et al. melaporkan bahwa kitosan dengan derajat deasetilasi antara 65 dan $80 \%$ dapat meredakan reaksi inflamasi dengan cara pembentukan jaringan granulasi dan osteogenesis. ${ }^{19}$ Howling et al. juga melaporkan bahwa ada hubungan antara derajat deasetilasi kitosan dengan proliferasi fibroblas yaitu kitosan dengan derajat deasetilasi yang tinggi (sekitar 89\%) dapat merangsang aktivitas proliferasi fibroblas dan menurun aktivitasnya jika derajat deasetilasi lebih rendah. ${ }^{16,20} \mathrm{Pe}-$ nelitian ini menggunakan kitosan dengan derajat asetilasi 75\%-85\% yang cukup mampu meningkatkan aktivitas proliferasi fibroblast yang bertanggung jawab dalam memproduksi kolagen sehingga dapat meningkatkan persentase kepadatan kolagen. Kitosan terbukti mampu merangsang perakitan serat kolagen pada matriks ekstraseluler di daerah luka ${ }^{21}$ sehingga kelompok II (kitosan 20\%) terbukti efektif pada variabel kolagen dilihat dari hasil yang menunjukkan persentase kepadatan kolagen yang lebih tinggi dibandingkan dengan kelompok kontrol. (Gambar 2)

Kitosan mengandung gugus $N$-acetylglucosamine yang dapat mengikat fibroblast growth factor-2 (FGF2) yang dihasilkan oleh makrofag. FGF2 akan merangsang proses proliferasi osteoblas dan sintesis tulang. ${ }^{16}$ Menurut Aranaz derajat deasetilasi (DD) yang cukup untuk dapat meredakan inflamasi adalah antara $75 \%-85 \%$. ${ }^{22}$ Kitosan dengan DD yang rendah cenderung terdegradasi lebih cepat. Hal ini membuktikan bahwa kitosan yang digunakan dalam pe- nelitian ini menunjukkan biokompatibilitas yang baik dan efek positif meredakan inflamasi dan dapat meningkatkan jumlah osteoblast pada soket pasca ekstraksi gigi marmot Cavia cobaya hari ke-14.

Kitosan merupakan polisakarida yang terdiri atas glukosamin yang mempunyai sifat osteokonduktif sehingga dapat merangsang pembentukan osteoblast dan menurunkan aktifitas osteoklas dengan cara menghambat aktifitas IL-6. ${ }^{18}$ Pada penelitian ini terbukti bahwa kelompok II (kitosan 20\%) efektif dilihat dari jumlah osteoklas yang menurun.

Hasil analisis statistik pada penelitian kelompok III dengan diisi spirulina $12 \%$ kitosan $20 \%$ menunjukkan adanya perbedaan yang signifikan terhadap persentase kepadatan kolagen, jumlah osteoblast, dan jumlah osteoklas dibndingkan dengan seluruh kelompok. Kelompok III paling efektif dibandingkan kelompok lain dalam mempercepat penyembuhan luka. Hal ini dikarenakan kandungan spirulina yang kompleks sehingga dapat mempercepat proses pengurangan respon inflamasi dan proses penyembuhan luka kemudian dikombinasikan dengan kitosan yang memiliki biokompatibilitas yang baik serta efek positif untuk meningkatkan jumlah sel osteoblast serta kolagen pada soket pasca ekstraksi gigi marmot Cavia cobayahari ke-14.Dosis tunggal kitosan memiliki kerugian jika digunakan sebagai pendukung dalam tissue engineeringkarena membran kitosan sangat kaku dan rapuh sehingga kitosan memiliki ketahanan mekanik yang rendah. Kitosan membutuhkan crosslinking agentssebagai kelompok reaktif fungsional yang memungkinkan untuk membuat jembatan rantai polimerik sehingga dapat mengoptimalkan ketahanan dan elastisitas kitosan agar mendapatkan biokompatibilias yang baik ${ }^{23}$ Kombinasi kitosan dengan biomaterial lain juga dapat memiliki efek sinergis pada adhesi sel, diferensiasi sel dan pembentukan matriks ekstraseluler. ${ }^{8}$ Pada penelitian ini terbukti bahwa kelompok III paling efektif pada semua variabel yaitu dilihat dari hasil variabel kolagen dan osteoblast yang jumlahnya meningkat serta variabel osteoklas yang jumlahnya menurun (Gambar 4).

Dari hasil keempat kelompok yang telah diteliti biomaterial yang paling efektif dan berpotensi pada soket pasca ekstraksi gigi hari ke-14 terhadap persentase kepadatan kolagen, jumlah osteoblast dan jumlah osteoklas adalah kelompok III dengan pemberian gel kombinasi spirulina $12 \%$ dan kitosan $20 \%$. Dosis gel kombinasi spirulina $12 \%$ dan kitosan $20 \%$ lebih efektif mempercepat penyembuhan luka jika dibandingkan dengan kelompok yang lainnya.

Hasil penelitian yang telah dilakukan induksi dengan spirulina $12 \%$, kitosan $20 \%$ dan kombinasi spirulina $12 \%$ kitosan $20 \%$ didapatkan hasil pemberian biomaterial kombinasi spirulina 12\% kitosan 
$20 \%$ yang diisikan pada soket gigi Cavia cobaya merupakan yang paling efektif sebagai bahan antiinflamasi untuk mempercepat proses penyembuhan tulang alveolar, sedangkan pada pemberian kitosan $20 \%$ kurang efektif untuk mempercepat proses penyembuhan tulang alveolar.

\section{UCAPAN TERIMA KASIH}

Penelitian ini dapat terlaksana dengan dana hibah Kolaborasi Dosen Mahasiswa Fakultas Kedokteran Gigi Universitas Airlangga Surabaya

\section{Daftar Pustaka}

1. Loekman M. Teknik dasar pencabutan gigi. Jurnal Ilmiah dan Teknologi Kedokteran Gigi 2006; 3: 82-84.

2. RISKESDAS Riset Kesehatan Dasar. Jakarta: Badan Penelitian dan Pengembangan Kesehatan, Departemen Kesehatan, Republik Indonesia 2007.

3. Brian Krans. Bone Graft. Healthline: Medically Reviewed. 2012. Available at http://www. Healthline.com/health/ bone-graft\#Risks3. Accessed on 6 April 2015.

4. Kabinawa INK. Spirulina: Ganggang penggempur aneka penyakit. Jakarta: Agro Media. 2006; 6-23.

5. Spirel. Benefits - Why Take Spirulina?. Available at http: //www.spirel.co.uk/benefits.asp.2012.Accessed on 6 April 2015.

6. Morais, de MG, Vaz B da S, Morais EG de, Costa JAV. Biological effects of spirulina (arthrospira) biopolymers and biomass in the development of nanostructured scaffolds. Hindawi Publishing Corporation. BioMed Research International. 2014; 4-5.

7. Ardakani FE, Azam AN, Yassael S, Fatehi F, Rouhi G. Effects of chitosan on dental bone repair. SciRes. 2011; (4): 200-205.

8. Griffon DJ, Abulencia J, Ragetly GR, Fredericks LP, Chaieb SA Comparative study of seeding techniques and three-dimensional matrices for mesenchymal cells attachment. J Tissue Eng Regen Med in Press. 2010; 169-179.

9. Rostiny, Kuntjoro M, Sitalaksmi MR, Salim S. Spirulina chitosan grl induction on healing process of cavia cobaya post extraction socket. Dent J. 2014; 47(1): 19-24.

10. Steiner, Gene G. The healing socket and socket regeneration. Compend Contin Educ Dent. 2008; 29(2): 114-6.

11. Sirois M. Principle and practice of veterinary tech- nology. St. Louis, Mo.: Mosby. 2004; 120.

12. Klopfleisch R. Multiparametric and semiquantitative scoring systems for the evaluation of mouse model. Histopathology - a systematic review. Veterinary Research. 2013; 9: 123.

13. Ding J, Ghail O, Lencel P, Broux O, Chauveau C, Devedjian JC, et al. TNF- $\alpha$ and IL-1 $\beta$ inhibit RUNX2 and collagen expression but increase alkaline phosphatase activity and mineralization in human mesenchymal stem cells. Life Sciences.2009; 84: 499504.

14. Neve A, Corrado A, Cantatore FP. Osteoblast physiology in normal and pathological conditions. Cell Tissue Res. Springer-Verlag. 2010; 1.

15. Sheweita, Khoskhal SAKI. Calcium metabolism and oxidative stress in bone fractures: Role of antioxidants. Current Drug Metabolism. 2007; 8: 519-25.

16. Howling GI, Dettmar PW, Goddard PA, Hampson F, Dornish M, Wood EJ. The effect of chitin and chitosan on theproliferation of human skin fibroblast and keratinocytes in vitro biomaterials. 2001; 22: 2959-66.

17. Rizeki MF, Fatmawati H, Wulandari P. Efek pemberian ekstrak buah pare (momordica charantia) terhadap kadar NF - kB (nuclear factor kappa beta) pada tikus wistar (rattus norvegicus) yang diberi diet aterogenik. Jember: Artikel Ilmiah Hasil Penelitian Mahasiswa. 2012; 1- 4

18. Triskayanti W. Peranan sitokin pada proses destruksi jaringan periodonsium. Fakultas Kedokteran Gigi Universitas Sumatera Utara. 2010; 1- 20.

19. Hidaka Y, Ito M, Mori K, Yagasaki H, Kafrawy AH. Histopathological and immunohistochemical studied of membranes of deacetylated chitin derivatives implanted over rat calvaria. J. Biomed. Mater. Res. 1999; 46: 418-423.

20. Azuma K, Izumi R, Osaki T, Ifuku, Morimoto M, Saimoto $\mathrm{H}$, et al. Chitin, chitosan, and its derivatives for wound healing: Old and New Materials. J. Funct. Biomater. 2015; 6: 108.

21. El SAO, El GTA, Abd EGTI. The effect of mesenchymal stem cells and chitosan gel on full thickness skin wound healing in albino rats: Histological, Immunohistochemical and Fluorescent Study. PLoS ONE. 2015: 10(9), 2.

22. Aranaz I, Mengíbar M, Harris R, Paños I, Miralles $\mathrm{B}$, Acosta N, et al. Characterization of chitin and chitosan. Curr. Chem. Biol.2009; 3: 203-230.

23. Vazquez MR, Ruiz VB, Zuniga RR, Koppel DAS, Olvera LFQ. Chitosan and Its potential use as a scaffold for tissue engineering in regenerative medicine. Hindawi Publishing Corporation. 2015: 5. 